\title{
Adolescents' Academic Boredom as Predictor of Peer Violence
}

\author{
Marijana Dragoslavić ${ }^{1}$, Vesna Bilić́
}

\begin{abstract}
Mario Martinolic primary school, 11 Omladinska St., HR-51550 Mali Lošinj, Croatia, marijana.dragoslavic1@skole.hr University of Zagreb, Faculty of Teacher Education, Department of Pedagogy and Didactics, 77 Savska road, HR-10000 Zagreb, Croatia, vesna.bilic@ufzg.unizg.hr
\end{abstract}

Annotation. The article problematizes two universal problems in modern schools - peer violence and experiencing boredom in the classroom, and their interconnectedness. The results of research conducted among 604 students with an average age of 13.9 years show that these are relatively common among adolescents and that academic boredom is a significant predictor of victimization and the commission of traditional and electronic peer violence, which should be taken into account when creating prevention programs.

Keywords: academic boredom, bullying, cyberbullying, school, students, risk factors.

\section{Introduction}

In everyday school life, two universal, serious, and prevalent problems are noticeable, and those are violence among students and boredom in class. Both problems are neither new nor unknown, it can be said that in different variations they have always existed and still co-exist in schools, nevertheless their interconnectedness is poorly explored.

These intriguing phenomena attract attention because of their prevalence and concern about the seriousness of their consequences. Thus, due to its prevalence, boredom in class has been described in literature as plague of modern society (Pekrun et al., 2010), and some authors suggest that peer violence is also taking on epidemic proportions (Wolke, 2017). Both peer violence and boredom at school have similar, negative effects on school outcomes (success, engagement, etc.) and student behavior (externalized and internalized problems, etc.) (Bilić, 2018; Dahlen et al., 2004; Isacescu, Struk, \& Danckert, 2017; Rupp and Vodanovich, 1997; Spaeth, Weichold, \& Silbereisen, 2015). They are also connected 
by the fact that peer violence and boredom are particularly pronounced during early adolescence when they reach their peak (Livingstone, Mascheroni, \& Staksrud, 2018; Vassou, Vassiou, Stavropoulos, \& Chaintouti, 2017). However, in relation to peer violence, which is favored and in the focus of interest of many scholars and practitioners, boredom is rather underestimated and perceived as a trivial, neutral phenomenon. One possible reason for ignoring boredom is that it represents an inconspicuous, discrete, silent emotion that is not prototypical, compared to intense emotions of anger and rage which are associated with peer violence. (Goetz, Frenzel, Hall, Nett, Pekrun, \& Lipnevich, 2014; Nett, Goetz, \& Daniels, 2010; Pekrun et al., 2010). And while the public is quite sensitized, and practitioners and scholars engaged around a program to combat peer violence, combating boredom are rarely talked about, it is accepted as something benign and common in school practice. Although the number of papers paying attention to this issue has increased in recent years, it seems that it has been surprisingly neglected, which contradicts its frequency and possible consequences (Nett et al., 2010; Pekrun et al., 2010; Tze, Daniels, \& Klassen, 2016).

Therefore, the purpose of this paper is to examine the relationship between academic boredom and violence and victimization among peers in the real and virtual world. As this is a relatively new, poorly researched relationship in the school context between two universal problems, we expect that the results could enrich knowledge about the relationship and role of academic boredom and other related school variables (success and school satisfaction) in predicting peer violence and victimization, and could also be encouraging to scientists for new research and useful to practitioners in creating prevention programs.

\section{Academic boredom, student success and school satisfaction}

In recent times, more and more attention is paid too many positive and negative emotions that students and their teachers experience in the educational context. Academic (school or educational) emotions include emotions related to the way of teaching and the learning process itself (Pekrun, Goetz, Titz, \& Perry, 2002; Sorić, 2014). Pekrun's (2006) theory of emotion control and value is a relevant and frequently used framework for analyzing academic emotions, among which boredom is classified in the group of emotions related to activities. According to this theory, boredom in school is a negative (unpleasant), unwanted, deactivating emotion, of relatively low valence (on average slightly unpleasant), susceptible to external influences, and is directly related to learning and teaching in the classroom (Goetz et al., 2014; Pekrun et al., 2010; Tze et al., 2016). Description of boredom often includes component determination (Pekrun et al., 2010, p. 532). It is emphasized that boredom is a transient, aversive state, and the student feels uncomfortable, tired, or frustrated (affective component) due to subjective interpretation and dissatisfaction with the situation. Boredom is characterized by low arousal (physiological component) and inability to maintain attention, mental fatigue 
and wandering thoughts, passive attitude and expectation of change from the outside, inability to perceive what is wanted and find meaning, and perception of time passing slowly (cognitive component). Although there is a tendency to abandon this situation or change activities (motivational component), there is often a lack of will and strength to do so (volitional component). Rarely any action is taken to reduce boredom, but change or encouragement from the environment is expected or desired. In students, boredom is observed in vocal, facial (yawning, blank stare) and bodily (body movements and posture, lying down) expression (expressive component).

Boredom is an emotion of relatively low intensity and fairly high frequency (Pekrun et al., 2010), as confirmed by the results of empirical research, and according to them, between 20 and $66 \%$ of adolescents often experience boredom at school (Martz, Schulenberg, Patrick, \& Kloska, 2018; Nett, Goetz, \& Hall, 2011; Pekrun et al., 2010; Yazzie-Mintz, 2010), and almost all students occasionally complain about boredom in class (Tze et al., 2016). In order to contribute combat against this widespread problem, it is necessary to analyze the possible causes of boredom in school, which Nett et al. (2010) classify as a) external, situational causes and b) dispositional characteristics of students.

Students themselves most often attribute boredom in school to external, contextual causes, primarily classroom activities, teacher work methods and pedagogical style, and an insufficiently stimulating environment (Vodanovich \& Watt, 2016; Westgate \& Wilson, 2018). A study (Yazzie-Mintz, 2010) conducted among American adolescents ( $\mathrm{N}=42,754)$ cited content that was uninteresting (81\%) and irrelevant (42\%) as the main reasons for boredom. Boredom most often occurs as a reaction to monotonous, repetitive teaching activities which lead to a feeling of satiety (Sharp, Hemmings, Kay, Murphy, \& Elliott, 2017; Spaeth et al., 2015; Toohey, 2001 according to Ušić, 2017). Traditionally, boredom is thought to be caused by a lack of cognitively challenging and diverse tasks and activities that are not aligned with students' competencies, needs, and interests (Pekrun et al., 2010; Sorić, 2014). Others point out that academic boredom is the result of understimulation or overstimulation and engagement, i.e., it is being increasingly correlated with conditions of high demands, competence, and control (Pekrun et al., 2010; Westgate \& Wilson, 2018). This is also confirmed by the results of the aforementioned research by Yazzie-Mintz (2010) in which the respondents mentioned insufficiently challenging (33\%) or too demanding (26\%) tasks as the main reasons for boredom. In addition, boredom is affected by the perception of how much some teaching activities serve a practical purpose (Westgate and Wilson, 2018), how useful and valuable the content is and how much it allows students to control learning outcomes (Vassou et al., 2017), and what is the generally perceived value of teaching and learning attendance (Pekrun et al., 2010). When it comes to teachers, boredom is also attributed to uninteresting, frontal way of working, incomprehensible presentation of teachers, poorly structured activities, and generally insufficient quality teaching in which students are not adequately engaged (Spaeth et al., 2015; Tze et al., 2016). In addition, as many as $35 \%$ of students cite the lack of interaction with the teacher 
as the reason for boredom (Yazzie-Mintz, 2010), which is also one of the main indicators of student dissatisfaction with the school. Namely, emotions experienced in school and different relationships with teachers affect student behavior and their satisfaction with school, directly, in either positive or negative direction, which is defined as the student's subjective cognitive assessment of overall and specific positive experiences in school (Whitley, Huebner, Hills, \& Valois, 2012). The aforementioned specific experiences related to a positive experience of oneself, one's academic and social abilities, and school success (Bubić \& Goreta, 2015). However, various studies show that between 16 and 80\% of students are dissatisfied with school (Huebner, Drane, \& Valois, 2000; Rees \& Main, 2016), and this is very worrying because children who are dissatisfied with their school experiences tend to have different adaptive difficulties, including academic failure, poor interpersonal relationships, and problematic behaviors, including peer violence (Whitley et al., 2012). Westgate and Wilson (2018) warn that the possible reason for boredom is dissatisfaction with school, and is associated with students' feeling that they are "stuck", "trapped" in the school environment primarily because of monotonous routines that cannot be avoided, and limit their autonomy. There is a possibility that boredom is also a way of expressing passive resistance of young people against adult supervision and institutional constraints that hinder the development of autonomy. However, Nett et al. (2010) suggest that responsibility for boredom cannot be solely on teachers and school, students must be responsible at least to some extent. It should certainly be said that in recent times the media has strongly influenced the perception that classes are generally boring as well as teachers' work and teaching methods. The media constantly offer students attractive, interesting, entertaining content, and in comparison to them, classes do seem monotonous. In addition, children and young people are being exposed to the ideal of a "comfortable life", a "comfort fever" in which the priorities are individual interests and the need for "continuous stimulation" (Lipovetsky, 2008). Today, students are fascinated by speed, they are in a continuous search for something new, interesting (Bilić, 2020), and avoiding boredom has been imposed on them as an imperative (Ušić, 2017). It is therefore not surprising that young people often use media as an escape from academic boredom, primarily for contacts with peers who are not always positive, in fact they are often inappropriate and violent, and often turn into cyberbullying.

As causes of academic boredom, some authors cite dispositional differences among students (abilities, individual interests) and their tendency to experience boredom more or less frequently (Nett et al., 2010; Sorić, 2014). To argue the thesis of dispositional reasons for boredom in school, Kass, Vodanovich, and Khosravi (2011) state that students who are bored at school are also bored outside of school. Boredom is associated with a personal sense of emptiness and lack of meaning and purpose (Pekrun et al., 2010; Vodanovich \& Watt, 2016), so there is talk of chronic or existential boredom (Westgate \& Wilson, 2018). Svendsen (2011) even defines boredom as absence of meaning. In literature, the propensity for boredom is associated with impulsivity and pursuit of sensation, difficulties 
in self-regulation, self-control, and thoughtfulness (Isacescu et al., 2017; Koban, Stein, Eckhardt, \& Ohler, 2018).

When it comes to coping with boredom in school, some students are directed towards changing perception of some aspects of the situation or activity, engage in meaningful activities, or use constructive, approach strategies (Sorić, 2014). Therefore, some authors point to potentially positive aspects of boredom (establishing new goals and exploring alternative possibilities, creativity); however, there is not much empirical evidence for this (Tze et al., 2016; Ušić, 2017). But students are more likely to focus on less aversive thoughts and behaviors that have nothing to do with the situation (daydreaming, talking to friends), so they use avoidant strategies. To reduce boredom, students often indiscriminately choose new goals, look for something fun, and most often use media for that purpose. McCoy (2016) confirms that in such situations almost $63 \%$ of adolescents spend time on unauthorized use of mobile devices, most often for correspondence with others (86.7\%), then sending e-mail (76.2\%), browsing virtual social networks (70.3\%), "surfing" the Internet (42.5\%) and playing video games (10\%). But boredom can also motivate them to engage in inappropriate activities that result in problems, such as cyberbullying (Westgate and Wilson, 2018).

Research unequivocally points to negative effects of academic boredom on motivation, superficial approach to information processing, intense difficulty concentrating on current activity, poor self-regulation, and this is reflected in student engagement, learning and success, but also educational outcomes (absenteeism and dropping out of school) and school satisfaction (Pekrun et al., 2010; Pekrun \& Linnenbrink-Garcia, 2012; Sorić, 2014; Tze et al., 2016). However, boredom is also associated with undesirable, deviant behaviors such as alcohol and drug consumption (Biolcati, Mancini, \& Trombini, 2018; Spaeth et al., 2015), and propensity to express anger, hostility, and aggression (Dahlen et al., 2004; Isacescu et al., 2017). Since peer violence is a subtype of aggressive behavior, it was reasonable to assume that it could be correlated with boredom. However, boredom is also associated with internalized forms of behavior, especially depression (Spaeth et al., 2015), which is assumed to be both a predictor and consequence of peer victimization (Bilić, 2018). The findings presented here were an impetus to examine the association between academic boredom and peer violence.

\section{Peer violence in a real and virtual world}

Peer violence is defined as malicious, hostile, and repeated or permanent, (direct or indirect) action of one or more peers of unequal actual or perceived physical strength, or psychological or social power, causing the other person to suffer physical, and / or emotional harm and feel powerless to resist and defend his or herself (Bilić, 2018; Olweus, 1998). The violence that occurs at school, i.e. in the real world, is usually called traditional, and its forms are most often classified as physical, verbal, and relational violence. Children behave in a similar way and with the same goals in the virtual world too, and 
at the same time they use electronic devices to inflict pain and harm on their peers, so we are talking about electronic violence which grows into cyberbullying.

This is undoubtedly a widespread problem, which is confirmed by the results of an international survey conducted in 42 countries $(\mathrm{N}=219,460)$, which shows that $4-35 \%$ of boys and $1-29 \%$ of girls experienced, and $1-34 \%$ of boys and $1-20 \%$ of girls committed traditional violence (Inchley et al., 2016). When it comes to cyberbullying, based on published works in the period from 2008 to 2015 , Zych et al. (2016) found that 4.6-78.3\% have been victims of electronic violence, and $2-56.5 \%$ have committed violence, with a warning that a large number of cases of cyberbullying remains unknown. It should also be added that a large number of children are exposed to multiple forms of violence. According to results of the latest research conducted by Cosma et al. (2020), which involved 764,518 students from 42 countries (EU and USA), it was found that $45.8 \%$ have been victims of cyberbullying, and an equal number experienced traditional violence ( $46.5 \%$ of boys and $45.3 \%$ for girls).

Peer violence is a very complex phenomenon, it can be influenced by a large number of individual, family, environmental, and school factors. The focus of this paper is school factors, primarily academic boredom, and school satisfaction and school success, which we assume may be related to peer violence in real and virtual worlds.

\section{The relationship between academic boredom, school satisfaction, school success and peer violence}

There is indeed little research on the relationship between boredom and peer violence. A connection has been found between boredom and traditional violence (Antoniadou, Kokkinos, \& Markos, 2016), and boredom has also been identified as a motivator for committing cyberbullying (Koban et al., 2018; Varjas, Talley, Meyers, Parris, \& Cutts, 2010). The findings show that boredom also predicts committing various forms of peer violence (Nocera, 2019; Vassou et al., 2017). Explanation of these findings highlights the link between academic boredom and expression of anger, hostility, and aggression (Fahlman, Mercer-Lynn, Flora, \& Eastwood, 2013; Isacescu et al., 2017), which may be associated with violence toward peers. We find a basis for examining the relationship between boredom and victimization in research which shows that anxiety sensitivity and depression as important characteristics of victims of peer violence (Bilić, 2018; Olweus, 1998) are associated with academic boredom, but also predict boredom (Isacescu et al., 2017; Nett et al., 2010), and that boredom and depression mutually reinforce each other (Spaeth et al., 2015).

What happens every day at school, positive and negative life experiences of students related to school context, such as boredom and problematic behaviors, especially peer violence, affect student satisfaction with school. Students who are unable to meet their needs at school and are not engaged enough are more likely to report that they are bored at school, and this is reflected in their satisfaction with school. On the other hand, dissatisfaction with school 
significantly contributes to withdrawal from participation in various school activities (Elmore \& Huebner, 2010). However, school satisfaction is also strongly influenced by negative interactions with peers. Students who perceive their peers as enemies and do not trust them, and participate in violence (as either perpetrators or victims) have been found to have lower levels of school satisfaction (Huebner et al., 2014; Varela et al., 2018).

Research shows that students who had the lowest scores on life and school satisfaction scale were less engaged in activities and also had the lowest average grades (Huebner et al., 2014). It has also been found that students with lower school performance are more likely to commit peer violence, but also experience it more often (Calmaestra, GarcíaVélez, \& Maldonado, 2018; Kowalski \& Limber, 2013; Parti, Schmidt, \& Neray, 2018). In particular, peer victimization is associated with lower average grades (Strøm, Thoresen, Wentzel-Larsen, \& Dyb, 2013). A meta-analytical review (Nakamoto \& Schwartz, 2010) involving 33 studies (a total of 29,552 participants) found a negative but low correlation between victimization and school success. But Jenkins and Demaray (2015) argue that this connection between victimization and school success is indirect and suggest that it may be mediated by feelings toward school. Accordingly, it is possible to assume that academic emotions, i.e., academic boredom as well as school satisfaction, can play an important role in the relationship between peer violence and school success.

In conclusion, school satisfaction and positive peer relationships correlate with both increased engagement and better academic performance (Huebner et al., 2014). Success and good relationships with peers usually make children more content, even happier, and their relationships with peers better. As student success is the focus of practice and educational policies today, attention is paid to ways of learning and teaching, while academic emotions, school satisfaction, and peer relationships are often overlooked. We expect this paper to contribute to explaining the role of insufficiently researched school variables (academic boredom, school satisfaction), which are reflected in success and peer violence. It should be emphasized that peer violence has a reciprocal effect on all aspects of students' lives.

Therefore, the aim of this study is to examine the roles of sociodemographic factors (age, gender) and school variables (boredom in class, school satisfaction, school success) in predicting victimization and peer violence. In accordance with this goal, the paper will examine the relationship between sociodemographic variables (age, gender) and selected school variables (boredom in class, school success, and school satisfaction) and peer violence. We expect a positive correlation between experiencing boredom in class and violence and victimization in a real and virtual world (Hypothesis 1) and a negative connection between these peer relationships and success and satisfaction with school (Hypothesis 2). After determining the nature of the relationship between the examined variables, the role of boredom in class, school success and satisfaction in predicting the commission of peer violence and victimization in a real and virtual world will be analyzed. We expect that it will be possible to predict violence and victimization in the 
real and virtual world based on the examined school variables, i.e. boredom in class, school satisfaction, school success (Hypothesis 3).

\section{Method}

\section{Respondents}

For the purposes of this research, with the aim of greater accuracy and generalization of results, Research Randomizer was used to select twenty-three schools from the Ministry of Education's list of primary schools, randomly selected from different regions of the Republic of Croatia (central, northwestern and eastern Croatia, Istria, Primorje and Dalmatia). The study ${ }^{1}$ involved 604 eighth graders from 21 elementary schools from whom consent was obtained. The average age of surveyed students was $13.9(\mathrm{SD}=0.418)$, while the gender structure was balanced ( $54 \%$ of girls $(\mathrm{N}=326)$ and $46 \%$ of boys $(\mathrm{N}=278)$ ).

\section{Data collection method}

After obtaining consent from school principals and written consent of parents of students, and the approval of the Ethics Committee of the Faculty of Teacher Education in Zagreb, while respecting all provisions of the Code of Ethics for research with children, data were collected by group examination in class. At the beginning of class, students were informed about the general goals and purpose of the research, the willingness to participate was clearly emphasized and the confidentiality of the collected data was guaranteed. They were told that, if they wished, they could withdraw from further participation in research at any time, but there were no such cases.

\section{Instruments}

The General Data Questionnaire contained questions about gender and age of students and school achievement in previous grade.

Scale of Boredom in Class (Trogrlić \& Sorić, 2014).

Originally, this Scale consists of 26 particles that relate to feelings a student experiences during class (for example: During class, I feel I am not using my abilities enough.). For the purposes of this research, four items on inappropriate use of digital devices during classes were added to the Scale (for example: During class, I secretly exchange text messages with

\footnotetext{
1 The data presented in this paper are part of a broader study, made on 1,208 respondents, conducted for the purpose of writing a doctoral dissertation entitled Friendship Quality and Violence Among Adolescents in Real and Virtual World. The dissertation was defended before an expert committee on July 9, 2020.
} 
friends on the Internet.), which increased the number of items to a total of 30 . Respondents have on a five-point scale ( $1=\mathrm{I}$ do not agree at all, up to $5=$ I completely agree) assessed the extent to which they experience the described conditions during classes. The reliability of this scale was checked and the Cronbach $\alpha$ was 0.945 . A total score of the Scale is determined as the sum of grades on all particles, and higher scores indicate higher levels of experience of boredom in class.

\section{Multidimensional Students' Life Satisfaction Scale (Huebner, 2001)}

Originally, this Scale consists of 40 particles divided into groups of factors related to specific areas of life: family, friends, school, living environment, personal. In this study, 8 items from the subscale were used to assess school satisfaction to examine how satisfied the respondent was with the school he / she attends (for example: I am looking forward to going to school.). On a five-point scale ( $1=$ not applicable at all to $5=$ fully applicable) respondents rated how satisfied they were with a particular area of their lives. The reliability of the subscale was checked, with Cronbach $\alpha$ being 0.834 . A higher score on that subscale indicates a child's greater satisfaction with these areas of his life.

Questionnaire on Violence Among School Children (Velki, 2012)

The questionnaire consists of two scales: the Violence Among Children Scale and the Victimization Scale, each of which consists of 19 particles divided into two subscales: traditional violence and cyberbullying/ victimization (for example I hit or push someone). Respondents have on a five-point scale $(1=$ never to $5=$ always $)$ assessed how often they experience or do what the claims state. The reliability of the scales used was also checked; the total Cronbach $\alpha$ for the Violence among Children scale is 0.908 , and for the Victimization Scale 0.911. The result for each subscale is formed on the basis of arithmetic means, with higher results on each scale indicating the child's more frequent acts or experiences of peer violence.

\section{Results}

In accordance with the set objectives and problems of this research and data processing plan, in the following paragraphs we first present the results of descriptive and correlation analysis, then the results of main regression analysis. In the analysis of the obtained results, parametric tests were used since the distribution of the obtained results was normal or was normalized by logarithmic functions. Table 1 shows descriptive indicators of sociodemographic (age, gender) and school (school success, school satisfaction, boredom in class) variables and violence committed and experienced in the real and virtual world. The self-reported average student achievement in the previous school year was 4.19 ( $\mathrm{SD}=0.784)$. The largest number of students had a very good $(44.5 \%)$ and excellent 
(38.6\%) average school performance, while fewer had good (14.9\%) and sufficient (1.5\%) average school success, and two students $0.3 \%$ ) repeated eighth grade.

\section{Table 1}

Descriptive Indicators of Age, School Success, School Satisfaction, Boredom in Class and Committed and Experienced Peer Violence

\begin{tabular}{lcccc}
\hline \multicolumn{1}{c}{ Variables } & M & SD & Min. & Max. \\
\hline Age & 13.97 & 0.706 & 13 & 16 \\
School success & 4.19 & 0.784 & 1 & 5 \\
School satisfaction & 2.75 & 0.854 & 1 & 5 \\
Boredom in class & 89.35 & 24.103 & 0 & 150 \\
Committed traditional violence & 1.32 & 0.509 & 1 & 5 \\
Committed cyberbullying & 1.19 & 0.376 & 1 & 5 \\
Experienced traditional violence & 1.71 & 0.678 & 1 & 5 \\
Experienced cyberbullying & 1.31 & 0.642 & 1 & 5 \\
\hline
\end{tabular}

The average value of school satisfaction assessment for the whole sample is $\mathrm{M}=2.75$ and $\mathrm{SD}=0.845$ and this is in line with some previously conducted research (Haranin, Huebner, \& Suldo, 2007; Huebner et al., 2000). Also, data obtained show that, unlike girls, boys are less satisfied with school (Mgirls $=2.82, \mathrm{SD}=0.838$; Mboys $=2.65$, $\mathrm{SD}=0.865 ; \mathrm{t}(602)=2.46, \mathrm{p}=.014)$. The average value of the assessment of boredom in class for the whole sample is $\mathrm{M}=89.35$ and $\mathrm{SD}=24.103$, which is higher than in previously conducted domestic and foreign research (Nett et al., 2011; Raccanello, Brondino, Moè, Stupnisky, \& Lichtenfeld, 2018; Sorić, 2014). Analyzes of gender differences show that girls, although they achieve a higher score overall, do not differ statistically significantly from boys in experiencing boredom in class (Girls $=88.81$, $\mathrm{SD}=25.014$; Boys $=87.42$, $\mathrm{SD}=27.209 ; \mathrm{t}(602)=0.65, \mathrm{p}=.514)$. Regarding committed peer violence, the results indicate that the respondents are more inclined to traditional than electronic forms of violence (Mtraditional $=1.32, \mathrm{SD}=0.509$; Melectronic $=1.19, \mathrm{SD}=0.376 ; \mathrm{t}(603)=16.05$, $\mathrm{p}=.000$ ); and more likely to engage in it are boys. Results of descriptive analysis for experienced peer violence show that students experience traditional violence more than cyberbullying (Mtraditional $=1.71, \mathrm{SD}=0.678$, Melectronic $=1.31, \mathrm{SD}=0.642 ; \mathrm{t}(603)=$ $18.51, \mathrm{p}=.000$ ) and no statistically significant differences were found between boys and girls. In accordance with the first and second problems and hypotheses on determining the relationship of sociodemographic and school variables (school success, school satisfaction, boredom in class) with violence and victimization of adolescents in the real and virtual world, a correlation analysis was performed using Pearson's correlation coefficient, and the results are shown in Table 2. It has been found that there is a low but statistically significant positive correlation between gender and results on the scale of assessment 
of student satisfaction with school $(\mathrm{r}=0.100 ; \mathrm{p}<0.05)$. The conducted analyzes further show that there is a low, but statistically significant negative correlation between gender and results on the measures of traditional violence $(\mathrm{r}=-0.123 ; \mathrm{p}<0.01)$ and cyberbullying $(r=-0.118 ; p<0.01)$, i.e., boys are more likely to behave violently towards their peers than girls. Regarding the relationship between victimization and gender, no statistically significant association was found, suggesting that boys and girls can be victims of peer violence equally often. Also, it has been found that experience of boredom in class is not statistically significantly associated with gender of students, i.e. boys and girls are equally prone to it. Given the age structure of the respondents, as expected, the results of this study did not establish a statistically significant relationship between age and school satisfaction, experiencing boredom in class, and various forms of peer violence, and one possible reason is that students in the sample were of similar age.

\section{Table 2}

Correlation Between Violence and Victimization of Adolescents in the Real and Virtual World and Sociodemographic and School Variables (School Success, School Satisfaction, Boredom in Class)

\begin{tabular}{|c|c|c|c|c|c|c|}
\hline & $\begin{array}{l}\text { School } \\
\text { satisfac- } \\
\text { tion }\end{array}$ & $\begin{array}{c}\text { Student's } \\
\text { perception } \\
\text { of boredom } \\
\text { in class } \\
\end{array}$ & $\begin{array}{l}\text { Violence - } \\
\text { traditional }\end{array}$ & $\begin{array}{l}\text { Violence - } \\
\text { electronic }\end{array}$ & $\begin{array}{l}\text { Victimization - } \\
\text { traditional }\end{array}$ & $\begin{array}{l}\text { - Victimization - } \\
\text { electronic }\end{array}$ \\
\hline Gender & $0.100^{*}$ & 0.025 & $-0.123^{* *}$ & $-0.118^{* *}$ & 0.041 & -0.032 \\
\hline Age & 0.028 & 0.006 & 0.009 & 0.005 & $-0.139^{* *}$ & -0.010 \\
\hline School success & $0.100^{*}$ & $-0.080^{*}$ & -0.005 & $-0.083^{*}$ & $-0.098^{*}$ & $-0.114^{* *}$ \\
\hline School satisfaction & - & $-0.529^{* *}$ & $-0.135^{* *}$ & $-0.080^{*}$ & $-0.086^{*}$ & $-0.084^{*}$ \\
\hline $\begin{array}{l}\text { Student's perception } \\
\text { of boredom in class }\end{array}$ & - & - & $0.255^{* *}$ & $0.155^{* *}$ & $0.248^{* *}$ & $0.261^{* *}$ \\
\hline
\end{tabular}

However, it has been found that younger students were more often victims of peer violence, but a statistically significant association was found only for victimization in the real world $(\mathrm{r}=-0.139 ; \mathrm{p}<0.01)$. Furthermore, although low, there is a statistically significant positive correlation between school success and school satisfaction $(r=0.100$; $\mathrm{p}<0.05$ ) and a negative correlation between school success and experiencing boredom in class $(\mathrm{r}=-0.080 ; \mathrm{p}<0.05)$. Thus, students with poorer success are more likely to experience classes as boring, but it is also possible that due to reduced desire to actively participate in work caused by boredom, they do not use all their potential and consequently achieve poorer results. A statistically significant negative correlation was found between school success and cyberbullying $(\mathrm{r}=-0.083 ; \mathrm{p}<0.05)$, which has also been confirmed in other studies (Calmaestra et al., 2018; Kowalski \& Limber, 2013; Parti et al., 2018). However, 
contrary to expectations, no statistically significant association was found between school success and traditional violence. School success was statistically significantly negatively correlated with victimization in the real $(\mathrm{r}=-0.098 ; \mathrm{p}<0.05)$ and virtual world $(\mathrm{r}=-0.114$; $\mathrm{p}<0.01$ ). Satisfaction with school is negatively correlated (correlation is statistically significant, although low) with experiencing boredom in class $(\mathrm{r}=-0.529 ; \mathrm{p}<0.01)$, traditional violence $(r=-0.135 ; \mathrm{p}<0.01)$ and cyberbullying among peers $(\mathrm{r}=-0.080$; $\mathrm{p}<0.05)$ and victimization in the real $(\mathrm{r}=-0.086 ; \mathrm{p}<0.05)$ and virtual world $(\mathrm{r}=-0.084$; $\mathrm{p}<0.05)$. Previous research on students' experience of boredom in class has linked this negative emotion almost exclusively to achieving academic success, but not to positive or negative peer relationships in adolescence. This study showed a statistically significant positive correlation between results of assessment of boredom in class and results of committing traditional violence $(\mathrm{r}=0.312 ; \mathrm{p}<0.01)$ and cyberbullying $(\mathrm{r}=0.224 ; \mathrm{p}<0.01)$. Regarding the relationship between boredom in class and victimization of adolescents, a statistically significant positive correlation was found between experiencing boredom during class and victimization in real $(\mathrm{r}=0.297 ; \mathrm{p}<0.01)$, but also in a virtual world $(\mathrm{r}=0.302 ; \mathrm{p}<0.01)$. Based on the obtained results, we conclude that Hypothesis 1 has been confirmed, i.e., the experience of boredom in class is positively correlated with committing and experiencing peer violence in the real and virtual world. Although we expected that school success and school satisfaction would be statistically significantly negatively correlated with violence and victimization in the real and virtual world, analyses showed that the negative correlation between school success and traditional violence was not statistically significant, so we conclude that Hypothesis 2 is partially confirmed. Thus, students with poorer school results, with a greater feeling of dissatisfaction with school and who are more bored in class, are more likely to experience peer violence, and they also commit some forms of violence.

Consistent with the third problem of this paper, we conducted a logistic regression analysis to predict whether a child would commit and experience peer violence depending on sociodemographic factors, school success, school satisfaction, and perceived boredom in class. The following predictors were used in the model: gender, age, school success, school satisfaction, and experience of boredom in class. A total of 4 logistic regression analyzes were performed for 4 different roles in peer violence, and the results are shown in Table 3. The results obtained show that gender and experience of boredom in class are statistically significant predictors of committing traditional violence and cyberbullying, while age, school success, and respondents' satisfaction with school did not show to be statistically significant. These predictors explain $10.6 \%$ of the variance of committed traditional violence and $4.3 \%$ of the variance of committed cyberbullying. From the results shown in Table 3, it is evident that traditional peer violence and peer cyberbullying are more often committed by male adolescents and those who are more bored in class. 
Table 3

Results of Logistic Regression Analysis for Criteria of Committed and Experienced Traditional Peer Violence and Peer Cyberbullying

\begin{tabular}{|c|c|c|c|c|}
\hline & $\begin{array}{l}\text { Committed } \\
\text { traditional } \\
\text { violence }\end{array}$ & $\begin{array}{l}\text { Committed } \\
\text { cyberbullying }\end{array}$ & $\begin{array}{c}\text { Experienced } \\
\text { traditional } \\
\text { violence } \\
\end{array}$ & $\begin{array}{l}\text { Experienced } \\
\text { cyberbullying }\end{array}$ \\
\hline predictors & $B(t)$ & $B(t)$ & $B(t)$ & $B(t)$ \\
\hline Gender & $-\mathbf{0 . 1 8 3}^{* \star}(-3.830)$ & $\mathbf{- 0 . 1 0 4} 4^{*}(-2.536)$ & $0.013(0.309)$ & $-0.028(-0.688)$ \\
\hline Age & $0.086(1.839)$ & $0.017(0.411)$ & $-0.084(-1.960)$ & $0.002(0.253)$ \\
\hline School success & $-0.042(0.882)$ & $-0.077(-1.849)$ & $-\mathbf{0 . 0 9 4} 4^{*}(-2.154)$ & $\mathbf{- 0 . 1 0 4} 4^{* *}(-2.627)$ \\
\hline School satisfaction & $0.033(0.597)$ & $-0.010(-0.202)$ & $0.028(0.552)$ & $0.064(1.369)$ \\
\hline $\begin{array}{l}\text { Student's percep- } \\
\text { tion of boredom } \\
\text { in class }\end{array}$ & $\mathbf{0 . 2 5 7 ^ { * \star }}(4.685)$ & $\mathbf{0 . 1 4 6} 6^{* *}(3.052)$ & $\mathbf{0 . 2 6 3}^{* *}(5.167)$ & $\mathbf{0 . 2 8 7 ^ { * * }}(6.133)$ \\
\hline $\mathrm{R}$ & $0.325^{* *}$ & $0.207^{* *}$ & $0.289^{* *}$ & $0.287^{* *}$ \\
\hline $\mathrm{R}^{2}$ & $0.106^{* *}$ & $0.043^{* *}$ & $0.084^{* *}$ & $0.083^{* *}$ \\
\hline
\end{tabular}

$\mathrm{F}$ change $=9.772^{* *} ; \mathrm{F}$ change $=5.309^{* *} ; \mathrm{F}$ change $=9.475^{* *} ; \mathrm{F}$ change $=10.612^{* *}$; df $1=5 ;$ df $2=413 \quad$ df $=5 ;$ df $2=590 \quad$ df $1=5 ;$ df $2=519$ df $1=5 ;$ df $2=590$

${ }^{* *} \mathrm{p}<.01 ;{ }^{*} \mathrm{p}<.05$

The regression analysis further showed that predictors (gender, age, school success, school satisfaction, and experience of boredom in class) explain $8.4 \%$ of the variance of experienced traditional violence and $8.3 \%$ of the variance of experienced cyberbullying. Of the predictor variables for predicting experienced traditional violence and cyberbullying, poorer school success and experience of boredom in class were found as statistically significant. Based on the obtained results, we conclude that Hypothesis 3 is partially confirmed since only the experience of boredom in class predicts the commission and experience of peer violence, school success predicts only victimization, and school satisfaction does not predict the analyzed negative relationships among adolescents. Also, based on the findings, it can be concluded that the impact of analyzed sociodemographic (gender, age) and school (boredom in class, success and school satisfaction) variables is limited and how they can explain only a small part of the overall variance in committing and experiencing peer violence in real and virtual world, which indicates possible importance of various individual, family, environmental and even other school factors (e.g. sense of connection, security, relationship with teachers, etc.). 


\section{Discussion}

The results of this research support the starting thesis that academic boredom, as well as peer violence, are widespread problems in everyday school life. A small number of students, only $11.6 \%$, state that their classes are not boring at all or mostly not boring. In contrast, $34.2 \%$ state that their classes are mostly boring, and $11.6 \%$ state that their classes are completely boring. $42.6 \%$ of respondents could not decide whether classes were boring or not, and no statistically significant differences were found in the experience of boredom in class between boys and girls. The existing literature also does not suggest consistent gender differences nor a clear role for gender being a predictor of boredom (Spaeth et al., 2015). So, about half of the students stated that they are bored in class, and similar results have been found in other countries. Thus, about half of young people in England (58\%) and China (50\%) experience academic boredom, and slightly less in Germany (44\%) and Canada (26-41\%) (according to Tze et al., 2016). However, the average value of assessment of boredom in the classroom is slightly higher in this study compared to previously conducted domestic and foreign research (Nett et al., 2011; Raccanello et al., 2018; Sorić, 2014). Certainly, the reason for this may be the use of various measuring instruments, but it is also worth noting that there is a continuous increase in academic boredom in schools around the world (Spaeth et al., 2015). The findings of this research also show that boredom is not a benign, trivial phenomenon, and in a way, they are a kind of critique of the situation in schools. Based on these findings, it can be concluded that the problem of academic boredom should not be underestimated and neglected, and on the other hand, it would be important that these findings be the basis and impetus for professional discussion on how to make teaching more interesting, attractive, and less boring.

One of the possible reasons for such results could be the age of the respondents, and in this case, they are eighth grade students, with their average age being 13.9 years. Other studies have also found an increase in boredom in students between fifth and eighth grade (Tze et al., 2016), i.e., that boredom increases at the age of 10-14 years (Spaeth et al., 2015). While explaining the propensity for boredom in early adolescence, Spaeth et al. (2015) state that during this period children have an increased tendency for sensations and immediate rewards, and the development of metacognitive abilities to regulate these needs occurs later in adolescence, which may make it difficult to cope with situations involving inadequate stimulation. At that time, the tendency to oppose the authorities is also expressed, so it can be understood as passive resistance to institutional and teacher supervision, requirements, and the like.

The literature cited in the theoretical part of the paper highlights the negative effects of boredom on school success and school satisfaction, and the results of this research are in line with that. Although low correlation was found between academic boredom and school success, it is statistically significant. It has been found that less successful 
students are more often bored in class and are more dissatisfied with school. In practice, it is well known that students who have difficulty attending classes or are not adequately stimulated are more often bored. Bad students often think that they do not understand certain content, it seems to them that they cannot successfully complete the tasks, so they do not make an effort, and since they do not work, they get bored. On the other hand, research has identified negative effects of academic boredom on motivation, selfregulation and access to information processing, and observed difficulties in concentrating on current activity, which adversely affects student engagement, learning, and these are possible reasons for poorer school performance (Pekrun et al., 2010, 2002; Pekrun \& Linnenbrink-Garcia, 2012; Sorić, 2014; Tze i ostali, 2016). Boredom is most often based on subjective impression that school activities are not meaningful or are demotivating, and time passes slowly (Spaeth et al., 2015) and therefore the feeling of dissatisfaction intensifies. Very often it is a feeling of dissatisfaction with the school. Regarding school satisfaction, the results of the assessment with regard to total achieved result showed that $21.22 \%$ of students are dissatisfied with school, $42.29 \%$ of them are satisfied, $30.51 \%$ are very satisfied, and only $5.97 \%$ of students are extremely satisfied with the school they attend. A statistically significant negative correlation was found between school satisfaction and experience of boredom in school, i.e., students who are more often bored in school are less satisfied with school. In addition to their success, students' satisfaction with the school is also influenced by their relationships with peers and teachers, which is cited in some research as the most important indicator of satisfaction with this area of student life (Weber \& Huebner, 2015). In the theoretical part, we also mentioned negative effects of boredom on risky behaviors of students in general, and this research adds empirical evidence of inappropriate behavior towards peers. According to respondents' selfassessment, a large number (68.6\%) stated that they were perpetrators of traditional forms (sometimes or rarely) of violence against peers, and $3.36 \%$ of them stated that they do so very often. Interestingly, a significantly smaller number (18.51\%) of the surveyed students were classified as occasional perpetrators of cyberbullying, and less than $1 \%$ stated that they are often or always violent towards their peers in the virtual world. Thus, according to respondents, they are more often involved in committing traditional forms of peer violence than electronic, which can be explained by their perception of cyberbullying as a form of joke or fun. Because in cases of cyberbullying, students cannot see the suffering of the victims and the consequences of their actions, they tend to relativize this form of violence. This again points to the need to raise awareness and educate students about types and consequences of all forms of peer violence, especially indirect ones, which are generally more difficult to notice and more often minorized.

However, when it comes to victimization, a large number (83.4\%) of students state that they have occasionally been victims of traditional forms of peer violence, and 5.2\% of them state that they are permanently or very often exposed to peer violence in the real world. A smaller number of students (39.7\%) were sometimes exposed to cyberbullying 
and $3.36 \%$ of them very often experience abuse in the virtual world. In general, it is easier to admit that we have experienced than to have done something bad. Because the approach to perpetrators of violence used in schools is often punitive, even when surveys are anonymous, students are more likely to give socially desirable responses.

The results of this research show that peer violence is a big and serious problem in Croatian schools as well, so the interest of scientists and concerns of parents and practitioners are not surprising. However, it should be noted that compared to international research (Inchley et al., 2016; Zych et al., 2016), a significantly higher number of students in the sample are classified as perpetrators of traditional forms of violence, while a smaller number of students in this sample refers to cyberbullying. It should be noted that differences in results are most often the result of using different measuring instruments, differently defined intervals in which violence occurred, and the operationalization of violence variables. As this is a frequent problem and makes it difficult to compare the results, there is a need to harmonize measuring instruments and more precisely determine different forms of peer violence.

One of the possible reasons for the obtained results on the worrying frequency of participation of surveyed students in various forms of peer violence is their age. Eighth grade students participated in this research, and researchers claim that peer violence reaches its peak in the seventh and eighth grade of primary school, i.e., in the period when students are 12 to 15 years old (according to Bilić, 2018, p. 143). Greater involvement of students in violence in this period can be explained by biological determinants of development, but social aspects are equally important, especially due to more intensive connections with peers. During these interactions, students face a series of demanding interpersonal situations for which they do not have sufficiently developed social skills and are therefore often frustrated and aggressive. During this period, there is a tendency to show independence and courage, and for this purpose, students often manifest insolent, rude, and even violent behavior towards peers, especially the weaker ones. Since eighthgrade students participated in this study, no statistically significant age association was found, nor its role in predicting different forms of peer violence, but it was expected that younger students were more likely to be victims of peer violence in the real world. Because younger children cannot oppose older or stronger peers they are more often victimized (Olweus, 1998), while in the virtual world this difference is completely irrelevant.

This study found that traditional peer violence and peer cyberbullying are more common in male adolescents, and that male gender is a predictor of violence, while boys and girls are equally likely to be victims of peer violence. Boys' propensity to commit peer violence is thought to be largely determined by biological factors (Björkqvist, 2018). Research indicates an association between violence and hormone levels (testosterone, adrenaline, etc.) in male preadolescents and adolescents (Kodžopeljić, Smederevac, \& Čolović, 2010). Namely, during this particular developmental period in boys the secretion of hormones, primarily testosterone, increases very rapidly and intensively, which affects the functioning of the 
brain, i.e., leads to more frequent excitement, anger, or anxiety, so they often respond aggressively to the slightest sign of provocation (Berk, 2015). Daly and Wilson (1994 according to Björkqvist, 2018) call this the "young men syndrome". However, male students are more involved in traditional direct forms of violence, especially physical and verbal, while girls are more prone to indirect forms, especially relational violence (Bilić, 2018). When it comes to electronic violence, the findings are quite inconsistent. The results of some research show that there are no differences in perpetration of cyberbullying with respect to gender (Beran \& $\mathrm{Li}, 2007$ ) or these differences are insignificant (Livingstone, Haddon, Görzig, \& Olafsson, 2011). In contrast, some authors report that girls are more likely to be involved in cyberbullying (Pornari \& Wood, 2010), while others argue that boys are more likely to do so (Salmivalli \& Pöyhönen, 2012; Wang, Iannotti, \& Nansel, 2009). In explaining the results that in relation to girls, boys are more often perpetrators of violence in the real and virtual world, it is certainly necessary to take into account the cultural context (Kodžopeljić et al., 2010). In practice, it is observed that boys are more inclined to use violence as a strategy of domination and are more willing to report their participation in the direct forms of violence. In part, this role is encouraged in the family, but also socially constructed. Upbringing often encourages competitiveness, power, victory at any cost for boys, and cooperation and solidarity are less represented (Bilić, 2018). Unlike girls, boys are allowed to express negative emotions, anger and aggression, open confrontation, and proving by manifesting physical strength. The media also contribute to this by presenting an ideal image of a man as strong, dominant, insensitive. So not surprisingly, boys define peer relationships on the basis of power, behave rudely and express anger, or simply act to prove themselves as "real" men, while suppressing or concealing emotions (sadness, shame, etc.) which can be perceived as a sign of weakness. As it is especially important for them in adolescence to create an image of themselves as "real", strong, powerful men, they are constantly proving themselves by various inappropriate actions and even violence against peers, and in return, they receive important rewards - popularity and status in the classroom and attention of the opposite gender.

This analysis also included school success, and it was found that students with poorer school performance were more likely to commit some form of cyberbullying. Association between school success and perpetration of cyberbullying has also been established in previous research (Calmaestra et al., 2018; Kowalski \& Limber, 2013; Parti et al., 2018). In school practice, it has become clear that poorer students are perceived as those who behave inappropriately, so it is not surprising that they are increasingly inclined to actually avoid traditional forms of violence, because for them they are most often punished. But the virtual world gives them the ability to do so anonymously and avoid unpleasant consequences, so it is no surprise that they are more prone to committing violence using electronic devices.

This research results indicate a low but statistically significant correlation between school success and experienced traditional violence and cyberbullying, and that school 
success predicts victimization in the real and virtual world. In a time when we are turned to success at all costs, it is not surprising that children who achieve poorer school results are often exposed to ill-intentioned criticism, teasing and even violence from their peers in the real and virtual world. It is known that any characteristic of children that distinguishes them from their peers increases the likelihood of victimization. As the results of this research show that most respondents achieve very good or excellent results, in this context poorer school success may be a risk factor for victimization. On the other hand, experienced violence negatively affects their school results and school satisfaction. According to the findings of this research, there is a slight negative but statistically significant correlation between school satisfaction and committing violence and victimization, i.e. students who are less satisfied with the school are more prone to violence, but are also more often victims of violence in the real and virtual world. However, dissatisfaction with school is not a statistically significant predictor of violence or victimization. Since school satisfaction and experience of boredom in class are negatively correlated, there is a possibility that dissatisfaction with this area of student life thus indirectly contributes to the act, but also to the experience of peer violence, so future researchers are suggested to examine it.

This study also found a low, but statistically significant positive correlation between boredom in class and committing traditional violence and cyberbullying. In addition, academic boredom is a statistically significant predictor of committed traditional peer violence and peer cyberbullying. These findings are consistent with previously cited research (Antoniadou et al., 2016; Koban et al., 2018; Nocera, 2019; Varjas et al., 2010; Vassou et al., 2017). The finding that academic boredom predicts commission of violence in the real and virtual worlds is quite expected, as boredom is associated with difficulties in self-regulating behavior, expressing anger, hostility, and various measures of physical and verbal aggression (Fahlman et al., 2013; Isacescu et al., 2017). This is supported by the results of some studies which found that perpetrators of violence, in relation to their peers, achieve the highest results on the scale of boredom (Çelebi \& Aliyev, 2017). On the other hand, although perpetrators of violence are not a homogeneous group, it is known that their basic common feature is increased aggression (Bilić, 2018). In addition, students who are bored in class and do not actually work find ways to fill their time and have fun (Varjas et al., 2010). Boredom is also a possible reason why they are looking for some new stimuli and activities to avoid the ordinary, banal and monotonous, in order to achieve a sense of interest or fulfillment. In their effort to avoid boredom, externalized behaviors, including teasing and peer violence, offer easily accessible excitement and immediate rewards. It is possible that they tend to practice such behaviors to alleviate feelings of boredom (Spaeth et al., 2015). Due to impulsiveness and striving for sensation, i.e., a conscious search for unusual, intense, possibly dangerous experiences (Koban et al., 2018), they try to get in direct contact with their peers in the classroom or in a virtual world, and tend to show hostile intentions and negative feelings, so it is not 
surprising that they participate in peer violence (Vassou et al., 2017). On the other hand, an increased level of hostility is associated with the tendency to devalue potential options for engaging in activities that could alleviate boredom (Isacescu et al., 2017). In other words, failure to self-regulate and expression of hostility are strongly associated with a propensity for boredom. Thus, certain levels of boredom due to inappropriate stimulation can lead adolescents to practice inappropriate behaviors, and according to the results of this research, violence against peers.

However, this research confirmed the connection between academic boredom and victimization, and that boredom predicts victimization in both real and virtual worlds, which is consistent with previously cited research (Isacescu et al., 2017; Nett et al., 2011). Students who fail to find something to drive, motivate or interest them in the classroom, and are aware that the time they spend this way is really unused, may develop feelings of indifference, alienation, unproductivity, and even depression. And as previously stated, boredom and depression are mutually reinforcing (Spaeth et al., 2015). Since indifference, anxiety sensitivity, and depression are also characteristics of victims of peer violence in the real and virtual world (Bilić, 2018; Olweus, 1998), it is possible to connect them with academic boredom. However, the mechanisms of this association need to be discovered, so it is suggested that future researchers do so.

\section{Methodological limitations}

Although this research provides important insights and can contribute to expanding knowledge, primarily about the role of poorly examined school factors in the prediction of victimization and peer violence, it does have certain limitations. Because a quasiexperimental design was used, causal inference was not possible. The research is based on self-statement of the respondents, and this could increase bias of the answers. And as this is an analysis of complex phenomena and relationships, for the sake of objectivity it would be important to include more sources for assessment such as teachers and objective school data and to analyze these relationships over time. As only eighth grade students participated in the research, this could affect the results, and it would be desirable to include students of different ages (grades), which would enable monitoring of trends in participation in peer violence, but also in relation to boredom.

\section{Conclusion}

This paper analyses relatively new and insufficiently researched relationships between academic boredom and other related school variables (school success and school satisfaction) in predicting peer violence and victimization. It has been found that academic 
boredom is a widespread problem in schools and that less successful students are more often bored in class and more dissatisfied with school. All of the school variables listed here correlate with peer violence and victimization. It has also been confirmed that a large number of students participate in peer violence, with perpetrators of violence more often being boys, while boys and girls can be victims of peer violence equally often. Thus, a statistically significant correlation was found between school success and traditional violence and cyberbullying, and also that poorer school success predicts victimization in both a real and virtual world. Although it has been found that students with poorer school performance are more likely to commit some form of cyberbullying, school success is not a significant predictor of committing either traditional violence or cyberbullying. Similarly, although it has been found that students who are less satisfied with the school are more prone to violence, but are also more likely to be victims of violence in the real and virtual world, dissatisfaction with school is not a statistically significant predictor of violence or victimization. However, the findings of this study indicate a positive correlation between academic boredom and victimization as well as committing traditional violence and cyberbullying, and that boredom is a statistically significant predictor of victimization and peer violence in the real and virtual world.

It can be concluded that combating boredom, which is unjustifiably neglected and downplayed, is one of important aspects in the prevention of peer violence. Because many school activities are not tailored to students' developmental needs, the mismatch between rapidly changing needs and real opportunities in the school context can lead to a decline in motivation and engagement and can generate academic boredom and, according to the results of this research, other serious problems, such as peer violence. Taking into account all of the above, timely detection of boredom in students and careful planning of classes, to avoid monotonous and demotivating situations in the classroom, is of utmost importance because it encourages cooperation, school satisfaction and student success, and reduces the possibility of children's involvement in peer violence.

\section{References}

Antoniadou, N., Kokkinos, C. M., \& Markos, A. (2016). Possible common correlates between bullying and cyber-bullying among adolescents. Psicologia Educativa, 22(1), 27-38. https:// doi.org/10.1016/j.pse.2016.01.003

Beran, T., \& Li, Q. (2007). The relationship between cyberbullying and school bullying. The Journal of Student Wellbeing, 1(2), 15-33. https://doi.org/10.21913/jsw.vli2.172

Berk, L. E. (2015). Child developmental psychology (8th ed.). Zagreb: Naklada slap.

Bilić, V. (2018). New perspectives, challenges and approaches to peer violence. Zagreb: Educational challenges and Faculty of Teacher Education

Bilić, V. (2020). Upbringing and growing up in digital age. Zagreb: Educational challenges. 
Biolcati, R., Mancini, G., \& Trombini, E. (2018). Proneness to boredom and risk behaviors during adolescents' free time. Psychological Reports, 121(2), 303-323. https://doi. org/10.1177/0033294117724447

Björkqvist, K. (2018). Gender differences in aggression. Current Opinion in Psychology, 19(17), 39-42. https://doi.org/10.1016/j.copsyc.2017.03.030

Bubić, A., \& Goreta, I. (2015). Academic and social determinants of general school satisfaction. Psihologijske teme, 24(3), 473-493. http://hrcak.srce.hr/index.php?show=clanak\&id clanak jezik=219519

Calmaestra, J., García-Vélez, T., \& Maldonado, A. (2018). Cyberbullying in Spain. In U A. C. Baldry, C. Blaya, \& D. P. Farrington (Eds.), International perspectives on cyberbullying: prevalence, risk factors and interventions (pp. 251-268). Cham: Palgrave Macmillan. https:// doi.org/10.1007/978-3-319-73263-3 11

Çelebi, F., \& Aliyev, R. (2017). The examination of perception of leisure boredom and bullying status of students of secondary education by comparison. Journal of the Faculty of Education, 18(1), 248-264. https://doi.org/10.17679/inuefd.306629

Cosma, A., Walsh, S. D., Chester, K. L., Callaghan, M., Molcho, M., Craig, W., \& Pickett, W. (2020). Bullying victimization: time trends and the overlap between traditional and cyberbullying across countries in Europe and North America. International Journal of Public Health, 65(1), 75-85. https://doi.org/10.1007/s00038-019-01320-2

Dahlen, E. R., Martin, R. C., Ragan, K., \& Kuhlman, M. M. (2004). Boredom proneness in anger and aggression: Effects of impulsiveness and sensation seeking. Personality and Individual Differences, 37(8), 1615-1627. https://doi.org/10.1016/j.paid.2004.02.016

Elmore, G. M., \& Huebner, E. S. (2010). Adolescents' satisfaction with school experiences: Relationships with demographics, attachment relationships, and school engagement behavior. Psychology in the Schools, 47(6), 525-537. https://doi.org/10.1002/pits.20488

Fahlman, S. A., Mercer-Lynn, K. B., Flora, D. B., \& Eastwood, J. D. (2013). Development and validation of the multidimensional state boredom scale. Assessment, 20(1), 68-85. https:// doi.org/10.1177/1073191111421303

Goetz, T., Frenzel, A. C., Hall, N. C., Nett, U. E., Pekrun, R., \& Lipnevich, A. A. (2014). Types of boredom: An experience sampling approach. Motivation and Emotion, 38(3), 401-419. https:// doi.org/10.1007/s11031-013-9385-y

Haranin, E. C., Huebner, E. S., \& Suldo, S. M. (2007). Predictive and incremental validity of global and domain-based adolescent life satisfaction reports. Journal of Psychoeducational Assessment, 25(2), 127-138. https://doi.org/10.1177/0734282906295620

Huebner, E. S., Drane, W., \& Valois, R. F. (2000). Levels and demographic correlates of adolescent life satisfaction reports. School Psychology International, 21(3), 281-292. https:// doi.org/10.1177/0143034300213005

Huebner, E. S., Hills, K. J., Jiang, X., Long, R. F., Kelly, R., \& Lyons, M. D. (2014). Schooling and children's subjective well-being. In U A. Ben-Arieh, F. Casas, I. Frønes, \& J. E. Korbin (Eds.), Handbook of child well-being (str. 797-819). Netherlands: Springer. https://doi.org/10.1007/978-90-481-9063-8 
Inchley, J. C., Currie, D. B., Young, T., Samdal, O., Torsheim, T., Augustson, L., Mathison, F., Aleman-Diaz, A. Y., Molcho, M., Weber, M., \& Barnekow, V. (Eds.) (2016). Growing up unequal: gender and socioeconomic differences in young people's health and well-being: Health Behaviour in School-aged Children (HBSC) study: international report from the 2013/2014 survey. (Health Policy for Children and Adolescents; No. 7). WHO Regional Office for Europe. https://www. euro.who.int/ data/assets/pdf file/0003/303438/HSBC-No.7-Growing-up-unequal-FullReport.pdf

Isacescu, J., Struk, A. A., \& Danckert, J. (2017). Cognitive and affective predictors of boredom proneness. Cognition and Emotion, 31(8), 1741-1748. https://doi.org/10.1080/02699931.2016 .1259995

Jenkins, L. N., \& Demaray, K. M. (2015). Indirect effects in the peer victimization-academic achievement relation: the role of academic self-concept and gender. Psychology in the Schools, 52(3), 235-247. https://doi.org/10.1002/pits.21824

Kass, S., Vodanovich, S., \& Khosravi, J. (2011). Applying the job characteristics model to the college education experience. Journal of the Scholarship of Teaching and Learning, 11(4), 56-68.

Koban, K., Stein, J. P., Eckhardt, V., \& Ohler, P. (2018). Quid pro quo in Web 2.0. Connecting personality traits and Facebook usage intensity to uncivil commenting intentions in public online discussions. Computers in Human Behavior, 79, 9-18. https://doi.org/10.1016/j. chb.2017.10.015

Kodžopeljić, J., Smederevac, S., \& Čolović, P. (2010). Frequency and manifestations of bullying: Differences between primary and secondary school students. Primenjena psihologija, 3(4), 289-305. https://doi.org/10.19090/pp.2010.4.289-305

Kowalski, R. M., \& Limber, S. P. (2013). Psychological, physical, and academic correlates of cyberbullying and traditional bullying. Journal of Adolescent Health, 53(1), 13-20. https:// doi.org/10.1016/j.jadohealth.2012.09.018

Lipovetsky, G. (2008). Paradoxical happiness. An essay on the hyperconsumer society. Zagreb: Antibarbarus.

Livingstone, S., Haddon, L., Görzig, A., \& Olafsson, K. (2011). Risks and safety on the internet: The perspective of European children. Full Findings. LSE. London. http://eprints.lse.ac.uk/33731/1/ Risks\%20and\%20safety\%200n\%20the\%20internet\%281sero\%29.pdf

Livingstone, S., Mascheroni, G., \& Staksrud, E. (2018). European research on children's internet use: Assessing the past and anticipating the future. New Media \& Society, 20(3), 1103-1122. https://doi.org/10.1177/1461444816685930

Martz, M. E., Schulenberg, J. E., Patrick, M. E., \& Kloska, D. D. (2018). “I am so bored!”: Prevalence rates and sociodemographic and contextual correlates of high boredom among american adolescents. Youth and Society, 50(5), 688-710. https://doi.org/10.1177/0044118X15626624

McCoy, B. R. (2016). Digital distractions in the classroom phase II: student classroom use of digital devices for non-class related purposes. Journal of Media Education, 7(1), 5-32.

http://digitalcommons.unl.edu/journalismfacpub/90 
Nakamoto, J., \& Schwartz, D. (2010). Is peer victimization associated with academic achievement? A meta-analytic review. Social Development, 19(2), 221-242. https://doi.org/10.1111/j.14679507.2009.00539.x

Nett, U. E., Goetz, T., \& Daniels, L. M. (2010). What to do when feeling bored?. Students' strategies for coping with boredom. Learning and Individual Differences, 20(6), 626-638. https://doi. org/10.1016/j.lindif.2010.09.004

Nett, U. E., Goetz, T., \& Hall, N. C. (2011). Coping with boredom in school: An experience sampling perspective. Contemporary Educational Psychology, 36(1), 49-59. https://doi.org/10.1016/j. cedpsych.2010.10.003

Nocera, T. (2019). Assessing the effects of psychopathy, sadism, aggression, and boredom proneness on cyber aggression perpetration in emerging adults: Is moral disengagement to blame? [Dissertation. The University of Southern Mississippi]. https://aquila.usm.edu/ dissertations/1712/

Olweus, D. A. (1998). Bullying at school: What we know and what we can do. Zagreb: Školska knjiga. Parti, K., Schmidt, A., \& Neray, B. (2018). Cyberbullying in Hungary. In A. C. Baldry, C. Blaya, \& D. P. Farrington (Eds.), International perspectives on cyberbullying (pp. 205-229). Chum: Palgrave Macmillan. https://doi.org/10.1007/978-3-319-73263-3 9

Pekrun, R. (2006). The control-value theory of achievement emotions: Assumptions, corollaries, and implications for educational research and practice. Educational Psychology Review, 18(4), 315-341. https://doi.org/10.1007/s10648-006-9029-9

Pekrun, R., Goetz, T., Daniels, L. M., Stupnisky, R. H., \& Perry, R. P. (2010). Boredom in achievement settings: Exploring control-value antecedents and performance outcomes of a neglected emotion. Journal of Educational Psychology, 102(3), 531-549. https://doi.org/10.1037/ a0019243

Pekrun, R., Goetz, T., Titz, W., \& Perry, R. P. (2002). Academic emotions in students' self-regulated learning and achievement: A program of qualitative and quantitative research. Educational Psychologist, 37(2), 91-105. https://doi.org/10.1207/S15326985EP3702_4

Pekrun, R., \& Linnenbrink-Garcia, L. (2012). Academic emotions and student engagement. In U S. L. Christenson, C. Wylie, \& A. L. Reschly (Eds.), Handbook of research on student engagement (pp.259-282). New York: Springer Science+Business Media. https://doi. org/10.1007/978-1-4614-2018-7

Pornari, C. D., \& Wood, J. (2010). Peer and cyber aggression in secondary school students: The role of moral disengagement, hostile attribution bias, and outcome expectancies. Aggressive Behavior: Official Journal of the International Society for Research on Aggression, 36(2), 81-94. https://doi.org/10.1002/ab.20336

Raccanello, D., Brondino, M., Moè, A., Stupnisky, R., \& Lichtenfeld, S. (2018). Enjoyment, boredom, anxiety in elementary schools in two domains: Relations with achievement. Journal of Experimental Education, 0973(May), 1-21. https://doi.org/10.1080/00220973.2018.1448747 
Rees, G., \& Main, G. (2016). Children's views on their lives and well-being in 15 countries: A report on the Children's Worlds survey, 2013-14 (2nd ed.). York, UK: Children's Worlds Project. https://eprints.whiterose.ac.uk/95207/1/8yearsoldreport.pdf

Salmivalli, C., \& Pöyhönen, V. (2012). Cyberbullying in Finland. In Q. Li, D. Cross, \& P. K. Smith (Eds.), Cyberbullying in the global playground: research from international perspectives (pp. 57-72). Chichester, England: Wiley-Blackwell. https://doi.org/10.1002/9781119954484.ch4

Sharp, J. G., Hemmings, B., Kay, R., Murphy, B., \& Elliott, S. (2017). Academic boredom among students in higher education: A mixed-methods exploration of characteristics, contributors and consequences. Journal of Further and Higher Education, 41(5), 657-677. https://doi.org/ 10.1080/0309877X.2016.1159292

Spaeth, M., Weichold, K., \& Silbereisen, R. K. (2015). The development of leisure boredom in early adolescence: Predictors and longitudinal associations with delinquency and depression. Developmental Psychology, 51(10), 1380-1394. https://doi.org/10.1037/a0039480

Svendsen, L. F. H (2011). A Philosophy of Boredom. Zagreb; TIMpress.

Sorić, I. (2014). Self-regulation of learning: Can we learn to learn? Jastrebarsko: Naklada Slap.

Strøm, I. F., Thoresen, S., Wentzel-Larsen, T., \& Dyb, G. (2013). Violence, bullying and academic achievement: A study of 15-year-old adolescents and their school environment. Child Abuse and Neglect, 37(4), 243-251. https://doi.org/10.1016/j.chiabu.2012.10.010

Trogrlić, I. \& Sorić, I. (2014). Boredom in Class Scale. In Ćubela-Adorić, V. i sur. (Eds.), Collection of psychological scales and questionnaires VII (pp. 7-14). University of Zadar Department of Psychology.

Tze, V. M. C., Daniels, L. M., \& Klassen, R. M. (2016). Evaluating the relationship between boredom and academic outcomes: A meta-analysis. Educational Psychology Review, 28(1), 119-144. https://doi.org/10.1007/s10648-015-9301-y

Ušić, E. (2017). About boredom: A draft for possible criticism. Narodna Umjetnost, 54(2), 69-82. https://doi.org/10.15176/vol54no204

Varela, J. J., Zimmerman, M. A., Ryan, A. M., Stoddard, S. A., Heinze, J. E., \& Alfaro, J. (2018). Life satisfaction, school satisfaction, and school violence: A mediation analysis for chilean adolescent: Victims and Perpetrators. Child Indicators Research, 11(2), 487-505. https://doi. org/10.1007/s12187-016-9442-7

Velki, T. (2012) Checking the ecological model of children's violent behavior towards peers. [Unpublished doctoral thesis.] University of Zagreb, Faculty of Philosophy, Zagreb.

Varjas, K., Talley, J., Meyers, J., Parris, L., \& Cutts, H. (2010). High school students' perceptions of motivations for cyberbullying: an exploratory study. The Western Journal of Emergency Medicine, 11(3), 269-273.

Vassou, V., Vassiou, A., Stavropoulos, V., \& Chaintouti, V. (2017). The Relationship between boredom, interpersonal closeness / bullying and victimization in the school environment. Psychology and Behavioral Science International Journal, 6(3). https://doi.org/10.19080/ pbsij.2017.06.555686 
Vodanovich, S. J., \& Watt, J. D. (2016). Self-report measures of boredom: An updated review of the literature. Journal of Psychology: Interdisciplinary and Applied, 150(2), 194-226. https:// doi.org/10.1080/00223980.2015.1074531

Wang, J., Iannotti, R. J., \& Nansel, T. R. (2009). School bullying among adolescents in the United States: Physical, verbal, relational, and cyber. Journal of Adolescent Health, 45(4), 368-375. https://doi.org/10.1016/j.jadohealth.2009.03.021

Weber, M., \& Huebner, E. S. (2015). Early adolescents' personality and life satisfaction: A closer look at global vs. domain-specific satisfaction. Personality and Individual Differences, 83, 31-36. https://doi.org/10.1016/j.paid.2015.03.042

Westgate, E. C., \& Wilson, T. D. (2018). Boring thoughts and bored minds: The MAC model of boredom and cognitive engagement. Psychological Review, 125(5), 689-713. https://doi. org/10.1037/rev0000097

Whitley, A. M., Huebner, E. S., Hills, K. J., \& Valois, R. F. (2012). Can students be too happy in school? The optimal level of school Satisfaction. Applied Research in Quality of Life, 7(4), 337-350. https://doi.org/10.1007/s11482-012-9167-9

Wolke, D. (2017). Cyberbullying: how big a deal is it? The Lancet Child and Adolescent Health, 1(1), 2-3. https://doi.org/10.1016/S2352-4642(17)30020-2

Yazzie-Mintz, E. (2010). Charting the path from engagement to achievement: A report on the 2009 High School Survey of Student Engagement. Bloomington, IN: Center for Evaluation \& Education Policy.

Zych, I., Ortega-Ruiz, R., \& Marín-López, I. (2016). Cyberbullying: a systematic review of research, its prevalence and assessment issues in Spanish studies. Psicología Educativa, 22(1), 5-18. https://doi.org/10.1016/j.pse.2016.03.002

\section{Paauglių mokyklinis nuobodulys kaip bendraamžių smurto prognostinis veiksnys}

\section{Marijana Dragoslavić ${ }^{1}$, Vesna Bilić ${ }^{2}$}

Mario Martinolić pradinė mokykla, Omladinska g. 11, HR-51550 Mali Lošinj, Kroatija, marijana.dragoslavic1@skole.hr Zagrebo universitetas, Pedagogų rengimo fakultetas, Pedagogikos ir didaktikos katedra, Savska kelias 77, HR-10000 Zagrebas, Kroatija, vesna.bilic@ufzg.unizg.hr

\section{Santrauka}

Šiuolaikinėse mokyklose vyrauja dvi universalios problemos - bendraamžių smurtas ir nuobodulys klasèse, tačiau apie jų tarpusavio ryši mažai žinoma. Tyrimo tikslas - ištirti sociodemografinių veiksnių (amžiaus, lyties) ir mokyklos kintamųjų (nuobodulys klasèje, 
pasitenkinimas mokykla, mokyklos sėkmè) vaidmenị prognozuojant bendraamžių persekiojimą ir tarpusavio smurtą.

Šio tyrimo tikslais, siekiant didesnio tikslumo ir rezultatų apibendrinimo, buvo pasirinktos dvidešimt trys mokyklos iš Švietimo ministerijos mokyklų sąrašo, jos atsitiktinai atrinktos iš skirtingų Kroatijos Respublikos regionų (Centrinio, Šiaurès Vakarų ir Rytų). Tyrime dalyvavo 604 aštuntokai iš 21 mokyklos. Iš mokyklos administracijos ir tèvų buvo gautas sutikimas tyrimui. Vidutinis apklaustų mokinių amžius buvo 13,9, o lyčių struktūra subalansuota taip: 54 proc. mergaičiu $(\mathrm{N}=326)$ ir 46 proc. berniukų $(\mathrm{N}=278)$.

Bendrųjų duomenų klausimyne buvo pateikti klausimai apie mokinių lytị ir amžių bei mokyklos pasiekimus ankstesneje klasėje. Kitas klausimynas buvo apie smurtą tarp moksleivių (Velki, 2012). Taip pat buvo naudojamos šios skalès: nuobodulio skalè klasèje (Trogrlić \& Sorić, 2014) ir daugiamatè gyvenimo pasitenkinimo skalè (Huebner, 2001).

Buvo nustatyta, kad mokyklinis nuobodulys ir bendraamžių smurtas yra gana plačiai paplitę tarp paauglių, o mokyklinis nuobodulys, pasitenkinimas mokykla ir mokyklos sėkmè koreliuoja su bendraamžių smurtu ir persekiojimu.

Mokyklinis nuobodulys pasirodè esąs reikšmingas tradicinių smurto ir elektroninių patyčių, aukų persekiojimo ir vykdymo tarp bendraamžių prognostinis veiksnys, ị kurị reikètų atsižvelgti kuriant prevencijos programas.

Esminiai žodžiai: mokyklinis nuobodulys, patyčios, internetinès patyčios, mokykla, mokiniai, rizikos veiksniai.

Gauta 20210308 / Received 08032021

Priimta 20210611 / Accepted 11062021 